\title{
A DISCOURSE-BASED VIEW IN INTERDISCIPLINARY APPROACHES TO FICTIONAL TEXT ANALYSIS
}

\author{
Alcina Sousa \\ University of Madeira \\ Colégio dos Jesuitas, Rua dos Ferreiros, 9000-082 Funchal, Portugal
}

\begin{abstract}
As patterns of communication change in a globalized society, literacy in foreign languages, especially English, becomes an issue of ever growing relevance to all those involved in the educational system, not to mention those who are to learn all their life long. As such, the goal of this article is to discuss how EFLit (English as a Foreign Literature) students can gain in both linguistic competence and critical awareness thereof, should their teachers/lecturers abide to a discourse-based view on (literary) language and approach the selected texts by following a pedagogical stylistics orientation also drawing eclectically on pragmatics and other areas of knowledge within the broader domain of applied linguistics. Here under focus will be a discussion of the topics on which literary and linguistic studies show greatest potential for (theoretical) convergence and, above all, combined applications in lecture setting. Crucially, it will be argued that a pedagogical stylistics approach to EFLit teaching/learning both develops students' linguistic competence and raises their awareness as to the meaning making potential of language in use in the texts at hand as well as in their larger historical and sociocultural settings. This will be illustrated by highlighting some textual features within a short extract of Fred D'Aguiar's The Longest Memory (1995) and the linguistic competence that its comprehension would demand from students.
\end{abstract}

Keywords: EFLit, pedagogical stylistics, reading, language and literary awareness, discoursebased view

\section{INTRODUCTION}

Most reading research in the twenty-first century shows that there is a common concern among teachers, researchers and educationalists dealing with the ways to address reading for different purposes and the diverse challenges (cf. Kamil, et al. 2001) in an era dominated by a wide panoply of media, with a focus on skills, strategies, dispositions, and practices required for successful online reading and reading achievement (Lankshear \& Knobel 2006, Leu et al. 2006, 2007, 2013, 2015, Leu \& Markel 2015).

The relationship between literariness and language has always been a contentious research topic. Ultimately, focusing on deviation from ordinary language (for instance Leech 1969), others on tropes and figures of speech (such as de Man 1979) and others still opting to think of literariness as a cline of layers of meaning (Carter 1997). It can thus be argued that the literary text, in which several registers, voices, modes blend and clash, challenges the reader with unfamiliar features, from graphology, semantics, lexis, syntax, coherence, cohesion and register (discourse) to pragmatics. When it comes 
to the threshold level, undergraduates' lexical competence and reading development might be fostered by allowing readers to interact with creative uses of language (Crystal and Davy 1985) not to be found in the usual class materials (i.e., manuals, dictionaries) as, among others, in the journalese, advertising or literary discourse. In this regard, Laura Calvo's contention extends the scope of language in use (2009: 17) to a wider panoply of discourse practices and communities to be studied by discourse analysts. Hence, it is necessary to reassess the contribution of an interdisciplinary approach to reading in an era where most information is encoded and processed in English, be it a mother tongue, second language or lingua franca.

In the scope of the issues to be discussed in the current paper, Gee's contentions from a discourse-based view (2001) seem relevant, given the focus on social context, the shared experiences and practices which are at the core of language interaction and meaning making, particularly concerning the multiple encounters in literary discourse to be equally fostered in the formal setting of education and literacy practices. To put it briefly and borrowing from Hall, Curtin and Rutherford (2014: 128), "language is given its meaning in use through its association with the situated meanings, cultural models and the sociocultural groups that socialize learners in communities of practice and literacy practices".

It is also worthy of reference a contrastive perspective from the readers' source language into the language in which the text is encoded (the target language). Thus, Hutcheon explains (1995: 120) within a pragmatics stance regarding the use of irony:

The flip side of this, a basically ethical position, is the one that says that the responsibility to guarantee the comprehension of irony (and the avoidance of misunderstanding) lies with the encoding ironist who must coordinate assumptions about codes and contextual information that decoders will have accessible to them, and be likely to use... The ethical dimension enters the intentionalist debate around irony in yet another way, though, for without the accountability that could come with intentionality, irony might well mean never having to say you really mean it. The potential for evasion through only tacit affirmation ... can be obviously viewed as a negative.

Extending the scope of discussion to reading literary texts, and the relevance of pragmatics in literary interpretation, Verdonk (1993: 2) sheds some light on the dilemma between interpretation and language competence (Durant 2001) resorting to the argument that "successful communication is the combined effect of textual (linguistic) competence and contextual (pragmatic) interpretation". Indeed, the various dimensions of speech act theory addressed by theorists such as Austin (1976), Grice (1991), Searle (1995), Iser (1993) and Traugott and Pratt (1980), as well as the theory of communicative action, grant an ideal field of inquiry in the contemporary paradigm of knowledge. Accordingly, conventions and assumptions of a culture are constantly being probed or reassessed whether in the local or in the global context, in interaction with other cultures, not to mention the literary forms and modes of oral communication and their reception in academic and other disciplinary contexts, too. The development of several theoretical strands within pragmatic stylistics, drawing on neo-Gricean and post-Gricean approaches, of which relevance theory (MacMahon 2006; Clark 2013) is a well-researched example, offers 
students/readers the possibility to read different (stretches of) texts with differing levels of analytical detail and precision as best suits their own reading interests (Clark 2014) in and beyond lecture setting (see Sousa 1997, 1998, 1999, 2000, 2002, Sousa \& Cíbiková 2016, Sousa \& Costa 2001).

Although there is not enough evidence about how L2 (second language) readers process texts syntactically, Urquhart and Weir (1998: 60) "suspect that they apply a collection of pragmatic strategies. For example, in English, the first [noun phrase] is likely to be the subject". Sousa (1994) has gathered evidence on metalinguistic awareness in the native and in the foreign languages reported to be significant related variables. A propos, Losonsky (1999), in his introductory note to Humboldt's ([1836] 1999) seminal writings on language, foregrounds pragmatic maxims (Grice 1991) in language negotiation and cooperation for meaning-making, particularly in that (1999: xxiii-xxiv) "language is first an activity of an individual speaker; people begin to speak because they must co-operate, communicate, and, most importantly, cultivate their own minds". Losonsky rightly puts two complementary issues related to pragmatics and the way it casts new light in the interpretation of literary texts, in the line of Humboldt's claims, (1999: xv):

1. For instance, speakers may have a clear distinction in mind between the subjunctive and future moods, but in their language-making power may be too weak to mind out the corresponding sounds. So even if laws governing the language-making power are the same everywhere, they differ in "intensity, veracity, and regularity".

2. Imagination and emotion will also contribute to diversity. "Imagination and feeling", he writes, "engender individual shapings, in which the individual character... emerges, and where, as in everything individual, the variety of ways in which the thing in question can be represented in ever-differing guises, extends to infinity". Language is rule-governed for Humboldt, but it is also like a work of art, and this dimension of language "cannot be measured by the understanding" and is "the deepest and inexplicable part" of language.

[author's emphases]

From the above it might be well advanced that it is deemed important to allow for pragmatic and cognitive approaches in the study of style and discourse which involve readers in a dynamic move beyond the literary text allowing them to grasp its meaning potential within the discursive and societal context. An example of the pedagogical potential lying in such pragmatics-inspired approaches to discourse is given by Semino's (2014) analysis of fictional narratives in which autistic characters experience instances of pragmatic failure in their attempts to communicate as a result of their condition. Benefitting from the detail and precision which characterise text stylistic analysis, such activities can allow for the discussion of wider societal issues that go beyond the text(s) and raise students' critical awareness of the (dis)continuities between fictional and non-fictional language use (Clarke \& Zyngier 2003). Thus, readers' intuition and simultaneous emotional involvement in the interpretation of texts, search to understand them in the light of those approaches, along with their usefulness in the process of meaning-making, will be a value-added issue. 


\section{TOWARDS A PEDAGOGICAL STYLISTICS APPROACH}

Within an applied stylistics paradigm borrowing extensively from discourse analysis, Naciscione (2001: 25) outlines the types of figurative meaning associated with the base form: metaphor, metonymy, hyperbole, understatement, allusion, oxymoron, euphemism, periphrasis, antonomasia, transferred epithet and irony. Hutcheon (1995: 122) has particularly discussed irony which requires "the discrimination of differences between said and unsaid", involving thereby (Op. cit., pp. 160, 174) "inferential skills" and "social cognitive development, (...) that operate on several different levels", notably on semantic and pragmatic levels. From her bearings, it might be concluded that anticipation, inference and presupposition equally call for (Op. cit., p. 174) "the ability to infer both the knowledge shared by speaker and addressee and the attitude of the speaker toward what is being" said.

What seems a common denominator, among many scholars and theorists, is rephrased by Carter as (1997: 138): "semantic densities and rereadings are activated by readers". Further on, he concludes (Op. cit., Ibidem) that "differently positioned readers may well frame different answers to questions concerning the nature of literary language". Given the eclectic and dialogic nature of the approach under discussion, readers are equally perceived as "interested parties", to subscribe Carter's contention (Op. cit., Ibidem), "willing, in certain sociolinguistic circumstances, to do interpretive work on all kinds of discourses if it appears contextually appropriate to do so".

Students/readers might also stand to gain from being exposed to the analytical methodologies employed by critical discourse analysts. As Reisigl (2011: 22) rightly points out, there are a number of theoretical and practical commonalities between pragmatics and critical discourse analysis (CDA) remarking that both tend "towards analysing language as a social phenomenon or practice, and language use in a social context", departing as well from the so-called genre analysis (Swales 1991). In this sense, by being instructed on the cognitive structures and functional and rhetorical effects of language in use (Hart 2014) in, for instance, media discourse, students/readers can draw some benefit. They are empowered to freely discuss their views and opinions with an analytical metalanguage and the theoretical bases that support it. From an EFL pedagogical perspective, such approaches to real discourse in the lecture setting can be said to have threefold benefits. Firstly, it requires students' intensive study to attain mastery over linguistic concepts and theory. Secondly, learners are empowered to use the target language, in this case English, to discuss professional and sociocultural issues which interest them, such as advertising (Cook 1992) and gender (Jeffries 2007), respectively. And lastly, a focus on discourse geared towards criticality can add to the diversity of lecture practice and, thus, engage more students in more ways. After all, as Porto \& Byram (2015) put it, "languages are best learnt when they are used for other things which are engaging and stimulating".

A pedagogical stylistics approach is aimed at enhancing "understanding... of the richness of language in its multiple uses" rather than "reducing appreciation of literary language use". Literary awareness is as vital in the interaction with literary discourse as language and culture awareness. This is one of the reasons for familiarising students/readers 
with all the analytical tools used in the understanding of literary discourse, including the many insights on deviation defended by different schools of criticism, though beyond the scope of the current paper.

The scheme enclosed underneath, though comprehensive in nature, aims at wrapping up in a schematic way what has been argued so far about the interactional nature of reading and the extent to which several disciplines, and not only literary criticism and linguistic analysis, have contributed to the search for understanding the reading of texts, from the production to the reception of meaning. Considering its complexity, it might be of utmost importance, for readability issues, to offer a staged but brief description of the three main blocks (at the core of the reading process) without overlooking the interrelationship of many of the components in the visual display.

Some of the disciplines, namely social sciences and applied linguistics, cognitive psychology, theories of interpretation and literary criticism, have been at times briefly touched upon because of their bearings to pedagogical stylistics. Furthermore, the schematic presentation seeks to bring together, in a selective fashion, the contribution of seminal scholars from various strands, displayed on the vertical dimension along three main blocks, concerning the reader, his/her interaction with the text and the text itself, which have come to offer a set of theoretical guidelines to explain the pedagogical stylistics approach as a (Carter 1994: 5) "crisscrossing"/interdisciplinary field.

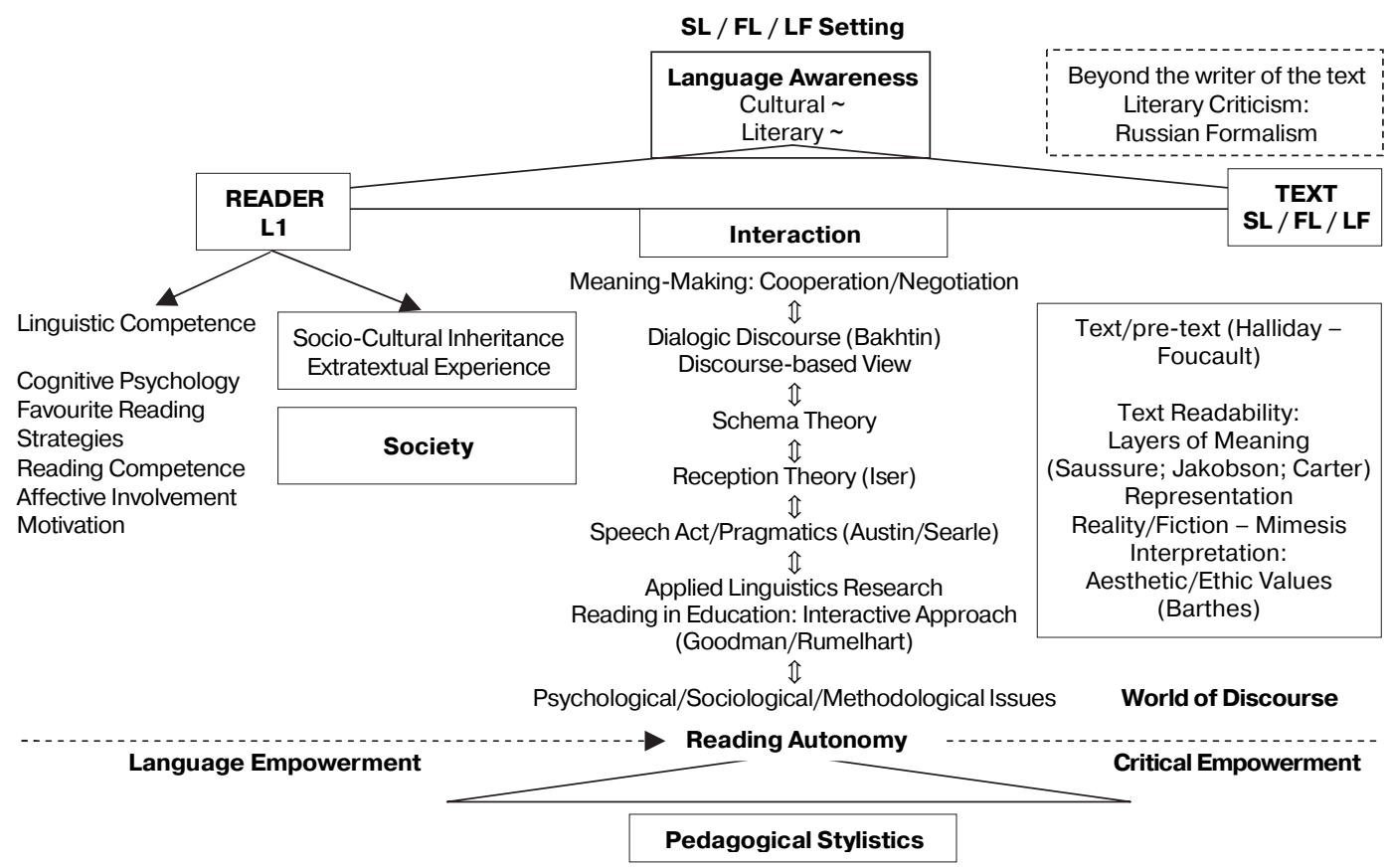

Fig. 1. EFLit READING — Interdisciplinary Approach

The principal horizontal dimension in the scheme depicts the reader and his/her interaction with a text, encoded in a foreign language, in this case English. The discontinued bottom line in the second horizontal dimension edging the graphical display, indicates the lifelong nature of language and critical empowerment underlying reading autonomy and exerting influence upon the individual's language, literature and culture 
awareness. In their quest to interact with the text, readers gradually improve their creative and critical skills.

At one end of the main axis there is the reader with the linguistic competence in his/her mother tongue, together with a basic knowledge of the foreign language, which are prerequisites for being able to identify as well as understand the code of the text.

Furthermore, Halliday and Hasan's ([1985] 1989: 117) "theoretical writings about language" will offer a counterargument to "a commonsense conception... that our ideas, our knowledge, our thoughts, our culture are all there — almost independent of language and just waiting to be expressed by it". Conversely, the authors have briefly argued that the speakers'/readers' awareness of language (Op. cit., Ibidem) "is so deeply rooted" in notions of linguistic and textual context, provided that "the notions of text and context are inseparable: text is language operative in a context of situation and contexts are ultimately construed by the range of texts produced within a community".

Naciscione (2001: 34) equally acknowledges the role of discourse awareness in the interpreting process:

In reading or listening the discourse is processed all the time whether consciously or not. The reader or the listener is concerned with an exceedingly complex inferential process in both written and oral discourse. Knowledge of the linguistic features of PUs [Phraseological Units] and their possible applications in discourse facilitates recognition and identification. It follows that inability to cope with ambiguities caused by a figurative interaction of language elements may inhibit comprehension and a faithful evaluation of the aesthetic and/or pragmatic implications of the text. Semantic and stylistic identification fosters comprehension and leads to more accurate interpretation of the relevant stretch of discourse.

McCarthy and Carter (1994: 168) further contend that "learners are likely to gain more interest and to be more empowered as educated citizens. Once again, a staged instruction on autonomous reading, depending firstly on the teacher's/lecturer's appropriate input at times (for instance, via scaffolding), recognisably facilitates individual experiences and understanding of texts (Rosenblatt [1938] 1999: 27). Also, less competent readers might benefit from teachers'/lecturer's strategic teaching of layers of meaning.

In the long run, readers not only become autonomous interpreters but also get acquainted with different text types along with dissimilar textual approaches. Their agency is fostered in their reading selection, not to mention their conscious choice of reading strategies appropriate to text types. Besides, they become responsive to language and literariness likely to be met in any discursive practice. It is thus reasonable that this stylistics approach borrows extensively from many bearings within the so-called wide field of pragmatics together with some pragmatic implications on many related fields such as semiotics and discourse analysis.

Departing from everyday language corpora and different domains, Cook (1992, 1994) argues that literariness occurs whenever a text affords a considerable challenge to readers' schemata - schema disruption — resulting in some cognitive change of view. This comprises either "schema refreshment" or "schema reinforcement". Drawing on his study of advertising language, Cook has offered some illustrations on both processes. In the case of proverbs, idioms, fixed phrases of readers' common knowledge, they acquire new meanings when the message is presented through linguistic deviation, in a dynamic creative way. 


\section{MEANING MAKING}

Linguistics, advance Traugott and Pratt (1980: 18), "can contribute a great deal to our understanding of a text". It is based on this premise that a pedagogical stylistics approach resorts to linguistics since it offers readers (Op. cit., Ibidem) "a vocabulary and a methodology through which" they can talk about their experience of a text, while focusing on their verbal structure. Yet, it is also true that the deconstructive theory will also contribute to open up the text, in which there is no final meaning. In readers' meaning-seeking, there should be an echo of Barthes's (1977) "The Death of the Author", in which there is an apology of the reader and a freedom of the text: its unity does not depend on its origin but on the interpretation. Moreover, Derrida's definition of a "text" ("Structure, Sign and Play in the Discourse of Human Sciences", 1972) as "a fabric of traces referring endlessly to something other than itself, to other differential traces" breaks the ties between signifier and signified, even though Saussure ([1959] 1966) had advocated the arbitrariness of the sign long before. As a consequence, the act of reading is an act of discovery (Derrida 1972), of différance. Meaning is not linear and there are as many readers as meanings/interpretations. Furthermore, "the act of interpreting texts" perceived from a stylistics stance, advances Carter (1994: 9), "involves a seeing through language to the ideologies which all texts reveal and conceal to different degrees" [scholar's emphasis]. In an EFL pedagogic setting, this sort of linguistic and meta-interpretational awareness can be augmented by resorting, for instance, to cognitive linguistic frameworks (see Giovanelli 2010). The metacognitive awareness of the role that students/readers take up in the process of reading enabled by lecturers' foregrounding of the links between "linguistic, contextual [form] and embodied knowledge in generating meaning" (Giovanelli 2016: 123) via their own perception and conceptualization systems offers new possibilities in terms of the development of literacy skills. If EFL students are acquainted with different codes (language system and its different uses), conventions and modes of the discourse (e.g., transactional language, interpersonal language and genre), they will not have to rely immediately on literary/critical theory to be able to tackle any text, be it literary or non-literary.

Indeed, and as Jeffries (2010: 16) rightly points out, while attempting to distinguish critical stylistics from critical discourse analysis, readers (students/lecturers) are first and foremost "concerned with stylistic choices, and the textual analysis which can illuminate the choices that a text producer has made, whether consciously or not". The framing of results borne by such textual analyses into a wider socio-political, literary, cultural or philosophical context can only come at a later stage after a rigorous linguistic analysis.

To reiterate the above contention, Crystal and Davy (1985) have offered a counter-argument either to many critics' claims on misinterpretations of literary texts in EFL language environments or to many researchers' suspicions concerning the reliability of literary interpretation. In their opinion ( $O p$. cit., pp. 4-5), "literature allows a greater range and more extreme kinds of deviation from the linguistic norms present in the rest of the language". These promote "an understanding of the varieties which constitute normal, non-literary language". At this point, it is pertinent to mention McRae's view on the prerequisites to teach English as a literary medium (1994: 35):

They [literary or linguistic schools] are just backup to the approaches but they are not something the teacher should worry about or be intimidated by... We want to say to the 
teacher: "Take the text as text and don't worry, just trust the text". There are no right or wrong answers, there are questions of interpretation, questions of imagination so that in the classroom, the student is encouraged in his/her own thinking, his/her opinion, to react even without language.

Based on a gradual instruction on different levels of meaning and layers of context, i.e. the linguistic context, the interactional context and the social context, to use Lier's terminology (1995: 40), readers, in this perspective either teachers or students, concentrate on words, cohesive ties (anaphoric, cataphoric and exophoric references or the troublesome demonstrative determiners and proforms), otherwise overlooked (Traugott and Pratt 1980), but determinant for the interpretation of any excerpt as well as for broader everyday literacy practices. A rigorous understanding of the discourse structures and persuasive power of advertisements, for instance, requires an elaborate awareness of lexico-grammatical choices and figurative language, as well as an awareness of sound patterning (effects) and (the cognition of) schematic language (Cockcroft, Cockcroft, Hamilton \& Hidalgo-Downing 2014).

While enhancing "interactional potentialities of texts" (McRae 1991: 18), the lecturer may upgrade students' knowledge of morphological and syntactical structures to a higher level of semantic unity of the whole text by means of a lecturer-student dialogue (Op. cit., Ibidem) "as a kind of pedagogical communicative relation" [author's emphasis]. Dialogue in education is perceived by Burbules (1993: xii) in the following fashion:

One of the mistakes often made in understanding dialogue is thinking that it is essentially like any other kind of conversation and that, since we all know how to have conversations, we must already know the basics of dialogue. People often use "dialogue" synonymously with "discussion", "chat", and related terms. But good, effective dialogue is much more difficult than ordinary conversation.

[author's emphases]

Reading between the lines (McRae and Boardman 1984), students'speaking and sharing their own voices, along with writing their own texts (comprising thus forms of dialogue), ultimately promote language, text and literary awareness, or as Morgan (1997: 13) puts it, a "self-empowering act". In addition, looking for cohesive ties in a text, for example, or "clues", to borrow from Rumelhart's (1984) illustration of the process of text comprehension (and its bearings with schema theory), might illustrate how the latter is thought to operate. His line of reasoning stands out for resorting to narrative clues understood to (Rumelhart 1984: 18) "suggest possible instantiations of schemata which are then evaluated against the successive sentences of the story until finally a consistent interpretation is discovered".

Finally, and before drawing on final considerations, a passage is provided to illustrate how the process of text/excerpt understanding might be monitored in an EFL language course. Students/readers are likely to perceive that, while reading for instance fiction, "authors... do not need to spell out every detail" (Rumelhart 1984: 19). Instead, they provide readers with "subtle clues which they can expect" them to pick up. Furthermore, and to tag along McCarthy and Carter's assertions (2001: 59), it is the goal now in this discussion to consider how "an integrative view of discourse influences the na- 
ture of the syllabus and the teaching that evolves from it", particularly when reading is placed at the core of EFL curriculum design.

All I could do was wait. My master delayed his departure to the North with his family and guests, until the trackers returned with my son. Mr Whitechapel was to accompany them to the next town, then return with his second son, William, leaving his wife and young daughter in the capable hands of his elder son, Thomas. I could do nothing but walk about the plantation sticking close to the main road up to the house, along which the party was sure to come bearing my son. The hours passed like an axle driven through mud. The usual sounds of industry around the plantation quietened as everyone listened for the approach of the overseer. Even the wildlife that sometimes made the place a veritable Eden with their cacophony were today flying about soundlessly and trotting through the woods on tiptoe. So it seemed to me with my eyes peeled for sign that my son was back and not consigned to a premature paradise.

The master threw up his arms as he emerged from the house with his family and guests. It was early afternoon. He said he could not delay his departure for Fredericksburg with his guests another minute, otherwise they would be on the road in the dark. He issued orders that my son was to be locked up to await punishment when he returned. Those were his parting words to the deputy. This deputy heard the order in the company of four slaves, myself not included. I was the fifth. Why my heart sank then I know now, but at the time I thought my alarm foolish and misplaced. How many times had the master left the plantation having issued orders that were carried out to the letter? Countless. This allayed my fears a little. I also reasoned that the trackers would pass him on the road on their way back and he would tell them in person. Then I remembered that a message had been sent to them to change the course of their pursuit of my son to the path alongside the river therefore any such meeting was unlikely.

[bold, underlined Mine]

Fred D'Aguiar, The Longest Memory (1995: 18 -19)

If students are not given any preliminaries about the text displayed above, their attention should be drawn to the first person pronoun reference "I", right at the beginning of the passage. This constitutes an anaphoric reference accounting for an omniscient (Emmott 2002) first person narrator, since, argues Culler (1994: 200), "in the case of first person narration, choices for which the reader can find no other explanation may be read as excesses which display the narrator's individuality and as symptoms of his obsessions".

Conversely, and by means of interactive reading of the passage, students/readers and lecturer gradually unveil the first person pronoun reference "I", as a cataphoric reference (through turn-taking), related to the proform "I was the fifth". By "suggesting a different emphasis from that attached to cohesion and reference", (in McCarthy and Carter 2001: 57) liable to come across in very many activities suggested in language through literature courses, readers end up pointing out a close relation between "I" and "the fifth slave", or the narrator/focaliser himself in the process of prediction, while concentrating on discursive markers, i.e., "then", forwarded by the unusual collocate "the party"/ "bearing my son", especially for EFL contemporary readers. From the contextual meaning, readers disclose its connotative meaning (such as group, assembly and chasers). 
Also, they may perceive a kind of beastly pleasure derived from setting an example through physical punishment, evidenced in the focaliser's euphemistic image. It is conveyed by a passive structure - "not consigned to a premature paradise" — without readers having to rely immediately on their background knowledge, but on experiential and procedural knowledge, instead.

The usual sounds of industry around the plantation quietened as everyone listened for the approach of the overseer. Even the wildlife that sometimes made the place a veritable Eden with their cacophony were today flying about soundlessly and trotting through the woods on tiptoe. So it seemed to me with my eyes peeled for sign that my son was back and not consigned to a premature paradise.

[emphases Mine]

The narrator's voice comes up to contrast with: the pronoun form in the third person "he" (a pronominal shift), and the binary "their pursuit"/ "my son ['s flee]". The latter is strongly marked by the possessive determiners, along with the omitted lexical item "flee", implicit in the use of the genitive form, namely in the utterance "their pursuit of my son" - the main theme of the excerpt. The intentional use of the cataphoric reference seems to have temporarily "delayed" (Derrida [1978] 1997) the meaning potential of the excerpt as well as readers' ever-increasing emotional commitment with the unfolding of events. This is also attained by the use of pronominal shifts to emphasise the characters' power relations in the literary discourse. These are marked by the binary empowered/disempowered (reinforced by tense, aspect and voice: "are to be returned"/ "returned") experienced by the "I" (the focaliser) in the crushing dilemma between "their" authority/pursuit and "he"/"my son"/the chased. The conflict is thus expressed by the liberating voice in the interior monologue and self-questioning complemented by the lexical choice, associated with the language of the oppressors, "my master", "the overseer", "the trackers" over the oppressed. The character ends up estranged from his own self, evidenced by the use of the appositive phrase "myself not included", as well as the simple clause "I could do nothing", both of which shift the readers' attention back to the opening sentence: "All I could do was wait".

Briefly sketched, and extending from the explanation provided by McCarthy and Carter (2001) on "how" to make meaning out of texts (within a strategic discoursebased syllabus), the point of entry hitherto considered, i.e., (grammatical and lexical) cohesion, has led to identify the semantic density of the excerpt, reinforced by other layers of meaning, such as lexis, register, syntax, period and style. The last one comprises the narrator's peculiar way/craft of conveying a highly emotive episode by making use of simple language albeit charged with a plurality of meanings. In short, posit the scholars (2001: 58), "there is every reason to suppose that knowing "what" [is meant] can inform and support knowing "how" [it is meant]".

In this fashion, McCarthy and Carter (2001: 59) foreground their discourse syllabus requiring from the student/reader the task of (in the line of Aston 1988) "a language observer" from the standpoint of a "discourse-analyst rather than as the sentence-parser and rule-discoverer of some approaches to traditional grammar-based syllabuses":

Ours is also an integrative view, wherein the over-arching perspective of language-asdiscourse will affect every part of the syllabus, including any conventional "system" (lexico- 
grammatical) components and functional/speech-act components, however they are treated, whether as a series of layers of language, or as realizations within general specifications of discourse strategies.

[authors' emphases]

Reading can, thus, be looked at as an integrative skill and a meaningful activity rather than a mechanical exercise, as it is frequently offered under the heading of "reading comprehension", followed by grammar and vocabulary exercises which leaves little to develop serious personal analysis and critical and imaginative skills without running the risk of undue speculation. In fact, a prescriptive approach to language education, for instance with a focus on the traditional grammar of usage, spelling and the correct styles, has been, to shortlist briefly some of the scholars cited by Lier (1995: 39), "condemned by many educators and linguists for a long time", such as Frye (1990), Halliday (1985, 1989), Sinclair (1991) and Fairclough (1992, 1995).

\section{FINAL CONSIDERATIONS}

In short, a pedagogical stylistics approach is aimed at enhancing "understanding... of the richness of language in its multiple uses" rather than "reducing appreciation of literary language use". Literary awareness is as vital in the interaction with literary discourse as language and culture awareness. This is one of the reasons for familiarising learners/readers with all the analytical tools used. A further motivation for bringing together different theories under a pedagogical stylistics approach to reading EFLit has to do with the potential to develop "the skills of critical interpretation of language" by grounding them on strategies which are activity-based rather than purely speculative and self-reflective. Texts are not only to be deconstructed but, as Carter wrote (1997: 83), are instead framed so as to equally undergo "construction and reconstruction" in a dialogical lecture setting. Taking a discourse-based view means sensitising students/readers towards the meaning potential of texts, literary or otherwise, by ensuring that they are given waysin to texts, and are empowered to explore the creativity and interactiveness of meaning creation in the reading/writing process.

(C) Alcina Sousa, 2017

\section{REFERENCES}

Aston, G. (1988) Learning Comity. Bologna: Editrice CLUEB.

Austin, J. (1976) How to do Things with Words: An Essay in the Philosophy of Language. Oxford: Oxford University Press.

Bally, C., Sechehaye, A. (eds.) (1966) Ferdinand de Saussure: Course in General Linguistics [1959] (trans. Wade Baskin). New York: McGraw-Hill.

Barthes, R. (1977) Image - Music - Text. New York: Hill and Wang.

Calvo, L. (2009) Perspectives on Discourse Analysis: Theory and Practice. Cambridge: Cambridge Scholars.

Carter, R. (1997) Investigating English Discourse: Language, literacy and literature. London and New York: Routledge. 
Carter, R. (1994) Teaching Literature: A View for the 90s. Greta, Granada, vol. 2 (2/Dec.), 5-10.

Clark, B. (2013) Relevance Theory. Cambridge: Cambridge University Press.

Clark, B. (2014) Pragmatics and Inference. In Stockwell, P., \& Whiteley, S. (eds.) The Cambridge Handbook of Stylistics (300-314). Cambridge: Cambridge University Press.

Clarke, U., \& Zyngier, S. (2003) Towards a Pedagogical Stylistics. Language and Literature, 12, 4, $339-351$.

Cockcroft, R., Cockcroft, S., Hamilton, C., \& Hidalgo-Downing, L. (2014) Persuading People: An Introduction to Rhetoric. Basingstoke: Palgrave Macmillan.

Cook, G. (1992) The Discourse of Advertising. London and New York: Routledge.

Crystal, D., Davy, D. (1985) Investigating English Style. New York: Longman,

Culler, J. (1994) Structuralist Poetics - Structuralism, Linguistics and the Study of Literature [1975]. London \& New York: Routledge \& Kegan Paul.

De Man, P. (1979) Allegories of Reading: Figural Language in Rousseau, Nietzsche, Rilke and Proust. New York: Yale University Press.

Derrida, J. (1978) Writing and Difference. Chicago: University of Chicago Press.

Durant, A. (2001) Comprehension and Problem-Solving in The Literature Classroom. The Nottingham Linguistic Circular 16, The School of English Studies, University of Nottingham, Nottingham, $1-18$.

Emmott, C. (2002) Split Selves in Fiction and in Medical Life Stories. In Semino, E. \& Culpeper, J. (eds) Cognitive Stylistics: Language and Cognition in Text Analysis,153-182).

Fairclough, N. (1992) Language and Power. Essex: Longman.

Fairclough, N. (1995) Media Discourse. London: Edward Arnold.

Frye, N. (1990) Anatomy of Criticism: Four Essays [1971]. New Jersey: Princeton University Press.

Gee, J. P. (2001) Discourse and Sociocultural Studies in Reading. Kamil, M., Mosenthal, P., Pearson, P., Barr, R. (2001) Methods of Literacy Research: The Methodology Chapters of the Handbook of Reading Research, Vol. III., chapter 9 (195-207), New Jersey/London: Lawrence Earlbaum Associates.

Giovanelli, M. (2010) Pedagogical Stylistics: A Text World Theory Approach to the Teaching of Poetry. English in Education, 44, 3, 214-231.

Giovanelli, M. (2016) Text World Theory as Cognitive Grammatics: A Pedagogical Application in the Secondary Classroom. In: Gavins, J., \& Lahey, E. (eds) World Building: Discourse in the Mind.

Grice, P. (1991) Studies in the Way of Words. Harvard: Harvard University Press.

Hall, H., Curtin, A., Rutherford, V. (2014) Networks of Mind: Learning, Culture, Neuroscience. London \& New York: Routledge.

Halliday, M. (1985) An Introduction to Functional Grammar. London: Edward Arnold.

Halliday, M. (1989) Spoken and Written Language [1985]. Oxford: Oxford University Press.

Hart, C. (2014) Discourse, Grammar and Ideology: Functional and Cognitive Perspectives. London and New York: Bloomsbury Academic.

Humboldt, W. (1999) On Language. In M. Losonsky (ed.). Cambridge: Cambridge University Press. Hutcheon, L. (1995) Irony's Edge: the Theory and Politics of Irony. London and New York: Routledge. Iser, W. (1993) The Fictive and the Imaginary: Charting Literary Anthropology. Baltimore: The Johns Hopkins University Press.

Jeffries, L. (2007) Textual Constructions of the Female Body. Basingstoke: Macmillan.

Jeffries, L. (2010) Critical Stylistics: The Power of English. Basingstoke: Palgrave Macmillan. 
Kamil, M., Mosenthal, P., Pearson, P., Barr, R. (2001) Methods of Literacy Research: The Methodology Chapters of the Handbook of Reading Research, Vol. III. New Jersey/London: Lawrence Earlbaum Associates.

Lambrou, M., \& Durant, A. (2014) Media Stylistics. Stockwell, P., \& Whiteley, S. (eds) The Cambridge Handbook of Stylistics. Cambridge: Cambridge University Press. Pp. 503-519.

Lankshear, C., \& Knobel, M. (2006) New literacies. 2nd ed. Maidenhead, UK: Open University Press.

Leech, G. (1969) A Linguistic Guide to English Poetry. London: Longman.

Leu, D. Castek, J., Hartman, D., (2006) Evaluating the development of scientific knowledge and new forms of reading comprehension during online learning. Final Report to North Central Regional Educational Laboratory/Learning Point Associates. Chicago, IL.

Leu, D. J., Zawilinski, L., Castek, J., Banerjee, M., Housand, B., Liu, Y., and O’Neil. (2007) What is new about the new literacies of online reading comprehension? In L. Rush, J. Eakle, \& A. Berger (eds.). Secondary school literacy: What research reveals for classroom practices. (37-68). Urbana, IL: National Council of Teachers of English. Available at http://www.newliteracies.uconn.edu/docs/whats\%20new\%20about\%20online\%20reading\% 20comprehension.pdf.

Leu, D. J., Kinzer, C. K., Coiro, J., Castek, J., Henry, L. A. (2013) New literacies: A dual level theory of the changing nature of literacy, instruction, and assessment. In Alvermann, D.E., Unrau, N.J., \& Ruddell, R.B. (Eds.). Theoretical models and processes of reading (6th ed.), 1150-1181. Newark, DE: International Reading Association. Available at: http://www.reading.org/ Libraries/books/IRA-710-chapter42.pdf.

Leu, D. J., Forzani, E., Rhoads, C., Maykel, C., Kennedy, C., Timbrell, N. (2015) The new literacies of online research and comprehension: Rethinking the reading achievement gap. Manuscript accepted for publication in Reading Research Quarterly, 50(1). doi:10.1002/rrq.85.

Leu, D. J., Maykel, C. (2015) Thinking in new ways and in new times about reading. Literacy Research and Instruction, 55 (2).

Lier, L. (1995) Introducing language Awareness. London: Penguin.

MachMahon, B. (2006) Relevance Theory: stylistic applications. In: Brown, K. (ed) Encyclopaedia of Language and Linguistics (519-522). Oxford: Elsevier.

McCarthy, M., \& Carter, R. (2001) Size isn't everything: spoken English, corpus and the classroom. TESOL Quarterly, 35, 2, 337-340.

McRae, J., \& Boardman, R. (1984) Reading between the Lines: Integrated Language and Literature Activities. Cambridge: Cambridge University Press.

McRae, J. (1991) Literature with a Small 'l'. London: Macmillan.

McRae, J. (1994) “An Interview with John McRae”. Greta, Granada, vol. 2 (2/Dec.), 35-41.

Naciscione, A. (2001) Phraseological units in literary discourse: implications for teaching and learning. Cauce: Revista de Filologia e su Didáctica, 24, 53-67.

Porto, M., \& Byram, M. (2015) Developing intercultural citizenship education in the language classroom and beyond. Argentinian Journal of Applied Linguistics, 3, 2, 9-29.

Reisigl, M. (2011) (Critical) Discourse analysis and pragmatics: Commonalities and differences. In Hart, C. (ed.) Critical Discourse Studies in Context and Cognition (7-27). Amsterdam/ Philadelphia: Johns Benjamins Publishing Company.

Rumelhart, D. (1984) Understanding Understanding. James Flood (ed.). Understanding Reading Comprehension. Newark: International Reading Association, 1-20.

Searle, J. (1995) The Construction of Social Reality. New York: Free Press. 
Semino, E. (2014) Pragmatic failure, mind style and characterisation in fiction about autism. Language and Literature, 23, 2, 141-158.

Sinclair, J. (1991) Corpus, Concordance, Collocation. Oxford: Oxford University Press.

Sousa, L. (1994) The Relation between Metalinguistic Awareness and Reading in the Native and the Foreign Language. Unpublished PhD dissertation. Azores: University of the Azores.

Sousa, A. (1997) Down with 'cribs': developing discourse competence". Proceedings of the $1^{\text {st }}$ International Conference on Discourse Analysis, Maria Emília Ribeiro Pedro (ed.), Lisbon, Portugal, May 1997, 103-124.

Sousa, A. (1998) Who cares about stylistics in an EFL classroom? Greta, 7 (1), 85-96.

Sousa, A. (1999) Who Cares About Stylistics in an EFL Classroom? In Greta, Adelina Espinosa and Bryan Robinson (eds.), Granada, Spain, vol. 7 (1), 85-96.

Sousa, A. (2000) Breaking the Ice with Literary Extracts: Old/New Voices in Ever Developing EFL Reading Contexts". ANPLI Proceedings $-8^{\text {th }}$ and $9^{\text {th }}$ Meetings, English - Diversity and Challenge, Braga, Portugal, 124-141.

Sousa, A. (2000) The clashing I's in literary and pedagogical discourse: André Brink's A Dry White Season in an EFL/Portuguese setting. PALA 19 Conference Papers, Discourses of War and Conflict, Annette Combrink and Ina Biermann (eds.), Potchefstroom, South Africa, 201-217.

Sousa, A. (2002) Is text analysis in EFL contexts reader-oriented/“real" student-oriented? - The Validity of Questionnaires in Pedagogical Stylistics? PALA Proceedings 21, Textual Secrets, The Message of the Medium. In Judith Mólnar and Szilvia Csábi (eds.), Budapest, Hungary, 2002, 513-524.

Sousa, A., \& Cíbiková, I. (2016) A Stylistics Approach to Canon Breaking Texts. Trnave: University of Ss. Cyril and Methodius.

Sousa, A \& Costa, D. (2001) Broadening horizons in stylistics: The multimedia lab as a challenging tool for text analysis in EFL contexts. CAUCE, Teaching and Learning Foreign Languages, John McRae (ed.), Seville, Spain, 2001, vol. 12/1, 175-184. Available at: http://dialnet.unirioja.es/ servlet/oaiart?codigo $=625278$.

Swales, J. (1991) Genre Analysis, English in Academic and Research Settings. Cambridge: Cambridge University Press.

Traugott, E., \& Pratt, M. (1980) Linguistics for Students of Literature. New York: Harcourt Brace Jovanovich.

Urquhart, A., \& Weir, C. (1998) Reading in a Second Language: process, product and Practice. London and New York: Routledge.

Waugh, L, Monville-Burston, M. (eds.) (1998) On Language: Roman Jakobson. Cambridge: Harvard University Press.

Verdonk, P. (ed.) (1993). Twentieth Century Poetry: From Text to Context. London \& New York: Routledge.

\section{Article history:}

Received: 18 January 2017

Revised: 18 February 2017

Accepted: 22 February

\section{For citation:}

Sousa, A. (2017). A Discourse-Based View in Interdisciplinary Approaches to Fictional Text Analysis. Russian Journal of Linguistics, 21 (2), 390-404. 


\title{
Bio Note:
}

Alsina Sousa, Dr, Assistant Professor (with tenure) at University of Madeira. Research interests: Applied Linguistics, Corpus Linguistics, Discourse Studies, Intercultural Communication, Rhetoric, Intercultural Pragmatics, Semantics, Discourse Analysis. Contact information: e-mail: alcina.sousa@staff.uma.pt

\section{ДИСКУРСИВНО-ОРИЕНТИРОВАННЫЕ МЕЖДИСЦИПЛИНАРНЫЕ ПОДХОДЫ К АНАЛИЗУ ХУДОЖЕСТВЕННЫХ ТЕКСТОВ}

\author{
Альсина Соуса \\ Университет Мадейры \\ Colégio dos Jesuitas, Rua dos Ferreiros, 9000-082 Фуншал, Португалия
}

\begin{abstract}
С изменением моделей коммуникации в ситуации глобализации изучение иностранных языков, особенно английского языка, становится все более важной проблемой для лиц, работающих в системе образования, не говоря о тех, кто должен поддерживать свой академический уровень на протяжении всей жизни. Целью данной статьи является обсуждение возможных способов наращивания языковой компетенции и навыков анализа языка обучающимися по программам EFLit. Соответственно, автор задается вопросом о том, должен ли преподаватель придерживаться основанного на дискурсивном подходе понимания (нормативного) языка и анализировать тексты, следуя принципам педагогической стилистики и учитывая знания прагматики и других областей знания в рамках более широкой области прикладной лингвистики. На первый план обсуждения в статье вынесены те области, которые в наибольшей степени подвержены конвергенции лингвистики и методики обучения языку. В частности, в статье показано, что педагогическая стилистика в обучении EFLit развивает учебные компетенции и повышает осведомленность учащихся о процедурах передачи языкового значения в рамках текста и, более широко, культурного и социального контекста. Анализ отрывка из книги Фреда Д’Агуайра «Насколько я помню» (1995) помогает понять, какие языковые компетенции требуются в процессе чтения для понимания этой книги.
\end{abstract}

Ключевые слова: EFLit, педагогическая стилистика, чтение, языковая грамотность, дискурсивный подход

\section{История статьи:}

Дата поступления в редакцию: 18 января 2017

Дата принятия к печати: 22 февраля 2017

\section{Для цитирования:}

Sousa A. A Discourse-Based View in Interdisciplinary Approaches to Fictional Text Analysis // Вестник Российского университета дружбы народов. Серия: Лингвистика. 2017. Т. 21. № 2. C. $390-404$.

\section{Сведения об авторе:}

Альсина Соуса, доктор, доцент кафедры английского языка Университета Мадейры (Португалия). Сфера научных интересов: прикладная лингвистика, корпусная лингвистика, анализ дискурса, межкультурная коммуникация, риторика, межкультурная прагматика, семантика, дискурс-анализ. Контактная информация: e-mail: alcina.sousa@staff.uma.pt 